\title{
Irodalom és identitás (Helyzetkép és feladatok)
}

Literature and identity: present situation and tasks

Littérature et identité (état des lieux et taches à remplir)

János Pusztay

\section{(2) OpenEdition}

\section{Journals}

Édition électronique

URL : https://journals.openedition.org/efo/4682

DOI : $10.4000 /$ efo.4682

ISSN : 2275-1947

\section{Éditeur}

INALCO

\section{Édition imprimée}

Date de publication : 1 janvier 2014

ISBN : 978-2-343-05394-3

ISSN : 0071-2051

\section{Référence électronique}

János Pusztay, «Irodalom és identitás (Helyzetkép és feladatok)», Études finno-ougriennes [En ligne], 46 | 2014, mis en ligne le 25 novembre 2015, consulté le 08 juillet 2021. URL : http:// journals.openedition.org/efo/4682 ; DOI : https://doi.org/10.4000/efo.4682

Ce document a été généré automatiquement le 8 juillet 2021

\section{(c) (†) 8}

Études finno-ougriennes est mis à disposition selon les termes de la Licence Creative Commons Attribution - Pas d'Utilisation Commerciale 4.0 International. 


\title{
Irodalom és identitás (Helyzetkép és feladatok)
}

\author{
Literature and identity: present situation and tasks \\ Littérature et identité (état des lieux et taches à remplir)
}

János Pusztay

\section{Az irodalom szerepe}

1 A nemzet kialakulásának hosszan tartó folyamatában az irodalom sok nép esetében játszott fontos szerepet. Az irodalom révén válhattak korábban ismeretlen népek ismertté - lásd a 19. század első felében a finn eposz, a Kalevala szerepét. Az említett finn eposz példája több szempontból is rendkívül érdekes. Hiszen olyan tényezők játszanak benne szerepet, amelyeket a mai ember már anakronisztikusnak tart.

- Az eposz mint műfaj a 19. század első felében már idejét múlta. Mégis, a finn eposz a finn öntudatra ébredés, a finn identitás kialakulásának kovásza lett, a i végül a finn függetlenséghez vezetett.

- Egyetlen egy ember szerepe. Elias Lönnrot, aki az egyetem elvégzése után körorvos lett Észak-Finnországban egy - akkori szempontból nézve - Isten háta mögötti településen, Kajaaniban, akkor, amikor még nem volt vasút, sem repülőgép, nem létezett telefon és internet, s mégis, sikerült rendkívül értékes anyagot gyüjtenie a finn eposz számára, s ezt a hatalmas értéket megszerkesztette, s vált - az eposznak köszönhetően - a finn szellemi élet vezető alakjává. Megalkotta több tudományág szakszókincsét, összeállította a finn nyelv leggazdagabb szótárát (csak a közelmúltban kiadott Nykysuomen sanakirja tartalmaz több szócikket, mint Lönnrot finn-svéd szótára).

2 A Kalevala megjelenésének köszönhetően vált Finnország világszerte ismertté.

3 Az eposz egyúttal sajátos láncreakciót is kiváltott.

- A finn eposz hatására született meg Észtországban az észt eposz megteremtésének gondolata, amelyet Kalevipoeg címen - Fählmann előmunkálatait is felhasználva Kreutzwald alkotott meg a 19. század második felének elején. 
- Az észt eposz vált a példaképévé a lett eposznak, amelyet Andrejs Pumpurs állított össze Lāčplēsis címen 1888-ban.

- Arany János a Kalevalától indíttatva, amelynek létéről Reguly Antal beszámolóiból szerzett tudomást, írta meg a hun-trilógiát.

- Úgy vélem, nem tévedek, ha feltételezem, hogy az oroszországi finnugor népeknek az utóbbi évtizedekben egymás után megjelenő eposzai is a Kalevala hatására keletkeztek.

\section{A mostani helyzet}

4 Az Orosz Föderáció finnugor népeinek helyzete bizonyos fokig hasonlít az észtek, finnek és magyarok 19. századi helyzetére. Mégis, sorsukban van néhány lényeges eltérés.

Ahogy tapasztalom, az oroszországi finnugor köztársaságokban - a nyelvről, kultúráról, iskolaügyről rendelkező törvények megléte ellenére - komoly problémák vannak. A törvények csak részlegesen működnek.

6 De nem ez az igazi probléma., hanem az, tisztelik-e maguk a finnugor népek a nyelvüket, kultúrájukat. Tapasztalataim szerint az anyanyelvhez, a saját kultúrához való viszony inkább csak szavakban nyilvánul meg, mintsem a tettekben. Sokakban a nemzeti öntudat helyett egy általános, oroszországi öntudat fejlődik ki. A homo sovieticus megteremtésének folyamatát a Szovjetunió szétesése után felváltotta a homo russlandicus létrehozásának igénye.

7 Ez a folyamat kihat a a finnugor népek folklórjára, a népdalok és néptáncok előadásmódjára, ami egyre inkább közelít a Mojszejev-együttes stílusára, s egyre jobban távolodik az eredeti finnugor hagyományoktól.

8 A finnugor irodalmi alkotások oroszra fordítása gyakran felismerhetetlen átköltései az eredeti műveknek. A kézenfekvő magyarázat: ezeket a műveket fel kell - úgymond emelni az orosz irodalom magas színvonalára, ám ezáltal éppen az alkotások sajátossága, eredeti íze, stílusa vész el.

\section{Feladatok}

- Meg kell teremteni annak feltételeit, hogy a jövőben is születhessenek irodalmi alkotások az oroszországi finnugor nyelveken.

- Különös gondot kell fordítani a gyermek- és ifjúsági irodalom művelésére. Az egyre inkább háttérbe szoruló anyanyelv népszerüsítésének az ifjúsági irodalom rendkívül fontos eszköze, s általa a fiatalok talán visszatalálnak a szülők vagy nagyszülők nyelvéhez.

- A finnugor népek irodalmát meg kell ismertetni a finnugor közösséggel - a művek kölcsönös fordítása révén.

-A világirodalom - s benne az orosz irodalom - legértékesebb alkotásait le kell fordítani az oroszországi finnugor nyelvekre, s lehetőleg eredetiből és nem az orosz közvetítésével.

- Rendszeres író-olvasó-találkozókat kell szervezni iskolákban, művelődési házakban városon és falun egyaránt.

- Meg kell oldani, hogy a finnugor nyelveken megjelenő szépirodalmi művek eljussanak az olvasóhoz. Jelenleg a könyvterjesztés privatizációja miatt legtöbb helyen falura egyáltalán nem jut el a könyv, mert az igényelt alacsony példányszám mellett ez a tevékenység a vállalkozónak nem kifizetődő. 
- Rendszeressé kell tenni a műfordítói szemináriumokat. Ilyeneket például finnek szerveznek oroszországi finnugor müfordítók számára. A müfordítás előfeltétele a nyelvek ismerete. A finnugor köztársaságok egyetemein be kell vezetni a finnugor nyelvek kölcsönös oktatását. Ez a mai technikai feltételek mellett nem költséges - videokonferencia formájában megvalósítható a virtuális mobilitás. (A Nyugat-magyarországi Egyetem Bölcsészettudományi Karán /Szombathely/ az Uralisztikai Tanszéken kidolgozták ennek az internet-alapú távoktatásnak és a videokonferencia biztosította interaktív kontaktórának a kombinációjával a nyelvoktatás hatékony módszerét. Ezzel a módszerrel megoldható volna anyanyelvi lektor alkalmazása nélkül is - a finnugor nyelvek kölcsönös tanítása.)

- Az oroszországi finnugor népek irodalmát meg kell ismertetni a világgal. Mindezt egyrészt azért, hogy gazdagodjon a világ kultúrája, másrészt viszont azért is, mert ezáltal növekszik a finnugor népek nyelvének, kultúrájának presztízse maguknak e népeknek a szemében. Egy átgondolt koncepció keretében az első jelentős lépéseket - túl a korábbi alkalmi, esetleges megoldásokon - mind Észtországban, mind Finnországban, mind Magyarországon megtették, különböző mértékben és hatékonysággal. Legyen elegendő Észtországban Arvo Valton grandiózus programjára gondolni, amelynek keretében több tucat jobbnál jobb oroszországi finnugor antológia, szerzői kötet látott napvilágot észt műfordításban, s a négynyelvű sorozatban oroszt és angol nyersfordításban is. Az oroszországi finnugor irodalmak fordítását és népszerüsítését nagyrészt egyfelől Raija Bartensnek, másfelől a Castrén Társaságnak lehet köszönni. Magyarországon főként Domokos Péter és Bereczki Gábor jóvoltából a korábbi évtizedekben számos irodalmi antológia, összeállítás jelent meg a finnugor népek irodalmából. Az utóbbi egy-két évtizedben Nagy Katalin adott ki néhány kötetet. A Nyugat-magyarországi Egyetem Uralisztikai Tanszékének - a számos nyelvészeti sorozata mellett - van Minoritates mundi -Literatura címen többnyire kétnyelvű irodalmi sorozata, amelynek eddig 25 kötete jelent meg, ebből 22 finnugor népek irodalmát tartalmazza. (A maradék három kötet a modern lett irodalomba nyújt betekintést.) Ebben a sorozatban adtuk ki például a Kalevala ötödik magyar nyelvű fordítását, emellett további finn és számos észt kötetet, de jelentek meg antológiák mordvin, komi, karjalai és vepsze irodalomból, valamint szerzői kötetek udmurt, mari és nyenyec alkotóktól.

9 Örömmel látom, hogy mind a finnugor köztársaságokban, mind a külföldön, pl. Észtországban tanuló oroszországi fiatalok körében jelentkeznek olyanok, akik vagy író- és költőpalántaként müvelik anyanyelvükön a szépirodalmat, vagy vállalják az irodalmi alkotások szerkesztését, kiadását és népszerüsítését. Például 2012-ben Észtországban tanuló mari egyetemisták közreműködésével jelenik meg fiatal mari költők antológiája észt, finn és magyar fordításban.

10 A finnugor szolidaritás megnyithatja az utat a minőségi irodalom számára a nemfinnugor világba is.

\section{Néhány szó a jövőről - magyar szemszögből}

11 2008-ban jött létre - alkalmi kormányzati támogatással - a Collegium Fenno-Ugricum elnevezésű intézet a Balaton északi partján, Badacsonytomaj városkában.

12 A könyvtárral, videokonferencia-berendezéssel ellátott intézet célja, hogy

- tudományos projekteket szervezzen a finnugor nyelvek fejlesztésének megsegítésére (például az oktatásban vagy akár a politikai életben szükséges terminológia kidolgozása érdekében); ennek eredménye a 2010-11-es tanévben megvalósított Terminologia scholaris program, amelynek keretében 5 oroszországi finnugor nyelven (erza, komi, mari, moksa, 
udmurt) 10 iskolai tantárgy (anyanyelv, irodalom, történelem, társadalomismeret, földrajz, matematika, fizika, biológia, kémia, informatika) szakszókincsét dolgoztuk ki a sziktivkári, szaranszki, joskar-olai, izsevszki egyetem szakembereinek közreműködésével és adtuk ki az 50 terminológiai kisszótárt (ennek szerkezete: a terminus az adott finnugor nyelven - a terminus oroszul - az annotáció az adott finnugor nyelven; a kötet végén orosz - finnugor regiszterrel),

- hozzájáruljon a finnugor közösséget bemutató ismeretek terjesztéséhez különböző nyelveken, köztük magukon a finnugor nyelveken is; ezt a célt szolgálja a Bibliotheca FennoUgrica sorozat, amelyben eddig hát oroszországi finnugor népről (karjalai, komi, komipermják, mari, mordvin, udmurt, vepsze) jelent meg tudományos-népszerűsítő kismonográfia kinek-kinek a saját nyelvén (a karjalaiak esetében két karjalai nyelvváltozatban, a mordvinok esetében erza és moksa nyelven) valamint oroszul. (Az orosz változat alapján lehetőség nyílik arra is, hogy bármely más finnugor vagy világnyelvre lefordítsák e munkákat.)

- kiadjon finnugor irodalmi kiadványokat - magyarul, illetve magyar irodalmat finnugor nyelveken; ebből a célból hoztuk létre a LiteratUral elevezésű programot, amelynek keretében eddig négy összeállítás jelent meg (egy-egy udmurt /Nadii Mus/, mari /Albertina/ és komi /Obrezkova/ antológia, valamint egy József Attila-antológia udmurt nyelven);

- szervezzen kurzusokat, nyári egyetemeket, továbbképző tanfolyamokat,

- bekapcsolódjon az Finnugor Egyetemek Asszociációjának munkájába (a fenti terminológiai projekt megvalósítása már ennek az asszociációnak a keretében zajlott).

\section{Zárásul}

Hozzájárulhat-e az irodalom az identitás fejlődéséhez és erősítéséhez? Meggyőződésem, hogy a kérdésre igennel lehet válaszolni. De csak akkor,

- ha az irodalom művelésének biztosítva vannak a politikai és a szakmai (például nyelvi) feltételei,

- ha van igény az irodalmi alkotások iránt,

- ha a finnugor irodalmak megőrzik sajátosságukat, s nem olvadnak bele más irodalmakba,

- ha megmarad és fejlődik a nyelv.

A feltételek biztosítása valamennyiünk feladata.

\section{BIBLIOGRAPHIE}

PUSZTAY János, 2001, A Kalevala - egy eposz és a nyelv. (A kultúra és az identitás kérdései)”, A

Kalevala végleges szövege 150 éves (A Magyar Tudományos Akadémián 1999. szeptember 14-én rendezett jubileumi tudományos ülés előadásai), Specimina Fennica IX, Savariae/Szombathely, p. 55-62.

PUSZTAY János, 2008, «ЛИТЕРАТУРА И САМОСОЗНАНИЕ», БУДУЩЕЕ ФИННО-УГОРСКИХ ЛИТЕРАТУР. ТВОРЧЕСТВО МОЛОДЫХ АВТОРОВ, МАРИЙ САНДАЛЫК - МАРИЙСКИЙ МИР, ЙОШКАР ОЛА. 